\title{
Fuel structure of the world's energy needs according to various development scenarios
}

ABSTRACT: The paper looks at an analysis of the tendency of changes in the fuel structure of electricity generation and thus resulting changes in carbon dioxide emissions. Forecasts drawn up by various institutions and organizations were selected for the analysis. Firstly, on the basis of statistical data contained in (IEA 2017a, IEA 2008) and with the use of Kay's indicators, the impact of changes in energy intensity of the national income and energy mix on changes in carbon dioxide emissions per capita in 2006-2015 for the OECD countries and Poland were analyzed. A small effect of changes was found in the fuel mix in this period of time on the emissions. The main impact was due to changes in the energy intensity of the national income and changes in the national income per capita. Next, selected fuel scenarios for the period up to 2050 (60) were discussed - WEC, IEA, EIA, BP, Shell, with a focus on the WEC scenarios. These have been developed for various assumptions with regard to the pace of economic development, population growth, and developments of the political situation and the situation on the fuel market. For this reason, it is difficult to assess the reliability thereof. The subject of the discussion was mainly the data on the fuel structure of electricity generation and energy intensity of national income and changes in carbon dioxide emissions. The final part of the paper offers a general analysis of forecasts drawn up for Poland. These are quite diverse, with some of them being developed as part of drawing up the Energy Policy for Poland until 2050, and some covering the period up to 2035. An observation has been made that some forecasts render results similar to those characteristic of the WEC Hard Rock scenario.

KEYWORDS: energy scenarios up to 2060, Fuel structure of electricity generation, changes in carbon dioxide emissions, energy scenarios for Poland

\footnotetext{
${ }^{1}$ Institute of Power Engineering and Turbomachinery. Silesian University of Technology: e-mail: tadeusz.chmielniak@polsl.pl
} 


\section{Introduction}

The main task of the energy policy of the EU and the entire globe is to reduce climate change and ensure safe and universal access to energy. The paths of achieving the desired goals are difficult to determine in the face of uncertainty regarding the assumptions of economic and social development in the long run. Individual institutions and organizations present their forecasts based on various assumptions which may facilitate the formulation of the energy policy and outline the restrictions on the implementation thereof. The aim of the article is to outline the current situation in the structure of energy consumption in the world and in Poland, as well as its changes in various available scenarios of energy development up to 2040 (2060).

\section{General characteristics of the current energy situation on a global and national scale}

According to data included in (IEA 2017a), the total primary energy consumption in 2015 in the world amounted to 13,647 Mtoe (Poland - 94.9 Mtoe, ie 0.7\%, in 2006 the relevant data is: 97.8 Mtoe, $0.832 \%$ ). In relation to 2006 , a global increase of $16.2 \%$ took place (consumption in Poland was reduced by $2.9 \%$ ). The share of fossil fuels (coal, oil, or gas) was $80.9 \%$ (2006) and $81.4 \%$ (2015). The data indicates moderate changes in the structure of primary fuels over the considered period. The trends become clearly visible when considering changes for individual geographical regions and countries. These are particularly observable for the OECD countries and China. In 2006, the share of OECD in global primary energy consumption was $47.2 \%$, while in 2016 it fell to $38.5 \%$. From 2006-2015, consumption decreased by 5\% (from 5537 to 5259 Mtoe). The economies of the OECD countries have been developing without increasing the demand for primary energy. The relative share of coal decreased from 20.8 (2007) to $17.1 \%$ (2016), oil from 39.2 to $36 \%$, gas increased from 22.6 to $26.9 \%$, and renewable sources (biomass + sun and wind, without classic hydropower) from 4.8 to $7.9 \%$. The share of China in global energy consumption has changed significantly. While in 2006 its share in primary energy consumption was $-16.2 \%$, that being 1902 Mtoe, in 2015 it was already $21.9 \%$, or 2989 Mtoe. Over the period under consideration, China increased its primary energy demand by $57 \%$. In 2006 , coal mining in China accounted for 46\% of world production (2549 Mt). Although in 2015 the relative share in global extraction did not change much (it amounted to $44.6 \%$ ), in absolute numbers the extraction reached the value of $3242 \mathrm{Mt}$, which means an increase of $27 \%$. The share of nuclear energy (by 203\%) and renewable sources significantly changed in the energy balance was. Changes in Poland are shown in Table 1. 
TABLE 1. Changes in primary energy consumption and electricity generation in Poland. The period 2006-2015 (2016) (KPE PAN 2010; IEA 2017a; IEA 2008)

TABELA 1. Zmiany w zużyciu energii pierwotnej i w wytwarzaniu elektryczności w Polsce. Okres 2006-2015 (2016)

\begin{tabular}{|l|l|}
\hline Primary energy 2006/2015 & The fuel structure of electricity generation 2006/2016 \\
\hline Total consumption 97.8 / 94.9 Mtoe & Generation of 147.7/166.6 TWh \\
\hline Energy carriers [\%] & Fuel structure [\%] \\
\hline Coal 57/55.66 & Coal 92/84.2 \\
Gas $12 / 14.21$ & Gas 3/3.5 \\
Oil and petroleum products 25/25.03 & Renewable energy sources 3.5/12.3 \\
Renewable Energy Sources and other 6.1/5.1 & Petroleum products are not included \\
\hline
\end{tabular}

Comparing the data presented in Table 1, it may be concluded that changes in the structure of consumption of primary energy carriers in the Polish economy have been made. Only a slight relative decrease in coal consumption (by 1.34\%) and an increase in gas consumption (by $2.21 \%$ ) have taken place. Taking a slight decrease in the total primary energy consumption into account (by 2.9 Mtoe, $3 \%$ ), changes in absolute values of individual energy carriers have also not been significant. In contrast to the trends characteristic of changes in the consumption of primary energy carriers, in the case of electricity generation there has been a noticeable reduction in coal consumption and a significant increase in production from renewable sources (wind energy). Data illustrating changes in the energy situation of Poland against the background of the World, OECD and selected countries is presented in Table 2. On the basis of this data one may conclude that there has been a slight increase in primary energy consumption per capita, with a noticeable increase in electricity consumption. The same applies to Poland. There has been a reduction in primary energy consumption per capita for the OECD countries, while the unit consumption of electricity has decreased. This situation has also occurred in the US, Germany and the Czech Republic.

The changes of these two indicators affected the emission of carbon dioxide. For a better interpretation of the causes thereof, the emission of $\mathrm{CO}_{2}$ ( may be written in the following form (using Kay's indicators)

$$
E_{\mathrm{CO}_{2}}(G t)=\alpha \beta \gamma P P
$$

Or unit emission as:

$$
\bar{E}_{\mathrm{CO}_{2}}=\frac{E_{\mathrm{CO}_{2}}}{P P}=\alpha \beta \gamma
$$

Where:

$$
\alpha=\frac{E_{\mathrm{CO}_{2}}}{T P E S}\left[\frac{\mathrm{GtCO}_{2}}{\mathrm{EJ}}\right]-\text { emission intensity, primary energy supply, }
$$




$$
\begin{array}{ll}
\beta=\frac{T P E S}{P K B}\left[\frac{\mathrm{MJ}}{\mathrm{USD}}\right] & - \text { energy intensity of gross national income, } \\
\gamma=\frac{P K B}{P P}[1000 \mathrm{USD}] & - \text { national income per capita, } \\
P P & - \text { population [billion], } \\
\text { TPES } & - \text { total primary energy supply. }
\end{array}
$$

TABLE 2 . Selected data regarding changes in energy consumption and electricity production

\begin{tabular}{|c|c|c|c|c|c|c|c|c|}
\hline \multirow[b]{2}{*}{$\begin{array}{c}\text { Country, } \\
\text { region }\end{array}$} & \multicolumn{2}{|c|}{$\begin{array}{c}\text { Consumption } \\
\text { of primary energy } \\
\text { [Mtoe (per capita, toe)] }\end{array}$} & \multicolumn{2}{|c|}{$\begin{array}{l}\text { Consumption of electric } \\
\text { energy }^{1} \\
\text { [TWh (per capita, kWh)] }\end{array}$} & \multicolumn{2}{|c|}{$\begin{array}{c}\mathrm{CO}_{2} \text { emission } \\
{\left[\mathrm{Mt}\left(\mathrm{t} \mathrm{CO}_{2} / \text { toe }\right)\right]}\end{array}$} & \multicolumn{2}{|c|}{$\begin{array}{l}\mathrm{CO}_{2} \text { Emission/GDP } \\
{\left[\mathrm{USD},\left(\mathrm{kg} \mathrm{CO}_{2} / \mathrm{GDP}-\right.\right.} \\
\mathrm{SNP})]\end{array}$} \\
\hline & 2006 & 2015 & 2006 & 2015 & 2006 & 2015 & 2006 & 2015 \\
\hline World & $\begin{array}{c}11740 \\
(1.8)\end{array}$ & $\begin{array}{l}13647 \\
(1.86)\end{array}$ & $\begin{array}{l}17377 \\
(2659)\end{array}$ & $\begin{array}{l}22386 \\
(3052)\end{array}$ & $\begin{array}{l}28003 \\
(2.39)\end{array}$ & $\begin{array}{l}32294 \\
(2.37)\end{array}$ & $\begin{array}{c}0.74 \\
(0.49)\end{array}$ & $\begin{array}{c}0.43 \\
(0.31)\end{array}$ \\
\hline OECD & $\begin{array}{l}5537 \\
(4.7)\end{array}$ & $\begin{array}{l}5259 \\
(4.12)\end{array}$ & $\begin{array}{l}9872 \\
(8381)\end{array}$ & $\begin{array}{l}10234 \\
(8016)\end{array}$ & $\begin{array}{l}12874 \\
(2.32)\end{array}$ & $\begin{array}{l}11720 \\
(2.23)\end{array}$ & $\begin{array}{c}0.44 \\
(0.41)\end{array}$ & $\begin{array}{c}0.24 \\
(0.25)\end{array}$ \\
\hline USA & $\begin{array}{c}2320.7 \\
(7.74)\end{array}$ & $\begin{array}{c}2188.3 \\
(6.8)\end{array}$ & $\begin{array}{l}4052.24 \\
(13315)\end{array}$ & $\begin{array}{c}4128.5 \\
(12833.25)\end{array}$ & $\begin{array}{c}5696.77 \\
(2.45)\end{array}$ & $\begin{array}{c}4997.5 \\
(2.28)\end{array}$ & $\begin{array}{c}0.51 \\
(0.51)\end{array}$ & $\begin{array}{c}0.3 \\
(0.3)\end{array}$ \\
\hline China & $\begin{array}{l}1897 \\
(1.44)\end{array}$ & $\begin{array}{l}2987 \\
(2.17)\end{array}$ & $\begin{array}{l}2716 \\
(2060)\end{array}$ & $\begin{array}{c}5593 \\
(4057)\end{array}$ & $\begin{array}{l}5648 \\
(2.98)\end{array}$ & $\begin{array}{l}9085 \\
(3.04)\end{array}$ & $\begin{array}{c}2.44 \\
(0.63)\end{array}$ & $\begin{array}{c}0.99 \\
(0.49)\end{array}$ \\
\hline Germany & $\begin{array}{l}348.56 \\
(4.23)\end{array}$ & $\begin{array}{l}307.8 \\
(3.77)\end{array}$ & $\begin{array}{l}590.98 \\
(7175)\end{array}$ & $\begin{array}{c}579 \\
(7015)\end{array}$ & $\begin{array}{l}823.46 \\
(2.36)\end{array}$ & $\begin{array}{l}729.8 \\
(2.37)\end{array}$ & $\begin{array}{c}0.41 \\
(0.37)\end{array}$ & $\begin{array}{c}0.20 \\
(0.21)\end{array}$ \\
\hline $\begin{array}{c}\text { Czech } \\
\text { Republic }\end{array}$ & $\begin{array}{l}46.05 \\
(4.49)\end{array}$ & $\begin{array}{l}42.1 \\
(4.0)\end{array}$ & $\begin{array}{c}66.85 \\
(6511)\end{array}$ & $\begin{array}{c}67.3 \\
(6384)\end{array}$ & $\begin{array}{l}120.97 \\
(2.63)\end{array}$ & $\begin{array}{c}99.6 \\
(2.36)\end{array}$ & $\begin{array}{c}1.67 \\
(0.62)\end{array}$ & $\begin{array}{c}0.44 \\
(0.32)\end{array}$ \\
\hline Poland & $\begin{array}{l}97.72 \\
(2.56)\end{array}$ & $\begin{array}{c}94.9 \\
(2.47)\end{array}$ & $\begin{array}{l}136.74 \\
(3586)\end{array}$ & $\begin{array}{c}154.1 \\
(4007)\end{array}$ & $\begin{array}{l}503.96 \\
(3.13)\end{array}$ & $\begin{array}{l}282.4 \\
(2.97)\end{array}$ & $\begin{array}{c}1.45 \\
(0.61)\end{array}$ & \\
\hline
\end{tabular}
from 2006-2015 (IEA 2017a; IEA 2008)

TABELA 2. Wybrane dane dotyczące zmian w zużyciu energii i produkcji elektryczności w okresie 2006-2015

${ }^{1}$ Gross production + imports - exports - losses.

In order to assess the change in emission unit within the considered period the following may be determined:

$$
\overline{C O}_{2}=\frac{\bar{E}_{\mathrm{CO}_{2}}(2015)}{\bar{E}_{\mathrm{CO}_{2}}(2006)}=\overline{\alpha \beta \gamma}
$$


Where:

$$
\alpha=\frac{\alpha(2015)}{\alpha(2006)}, \bar{\beta}=\frac{\beta(2015)}{\beta(2006)}, \bar{\gamma}=\frac{\gamma(2015)}{\gamma(2005)}
$$

The results of the calculation of $\overline{\alpha \beta \gamma}$ defined by formula (3) for the World and Poland using data from (IEA 2017a; IEA 2008) are shown in Figures 1 and 2 (for 2015, GDP is measured in USD 2010, and for 2006, USD 2000, SNP - money purchasing power determined also for 2010 and 2000 respectively). For all calculations carried out, $\alpha$ changes only slightly, so that the reduction of relative emissions is determined by the product $\overline{\beta \gamma}$. Where it is greater than 1 , then the effect is an increase in relative emission, while if economic changes make the product less than 1 , consequently, there is a decrease in $\overline{C O}_{2}$.

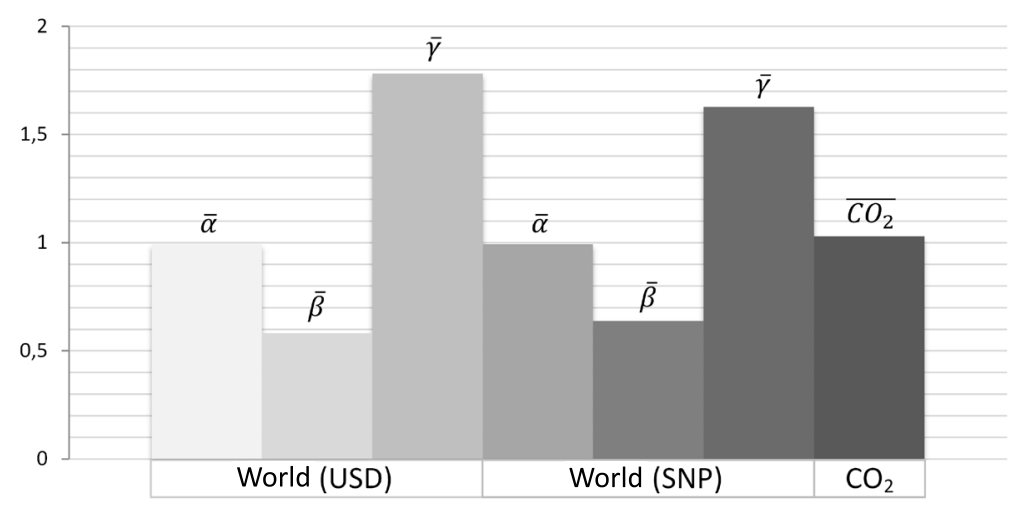

Fig. 1. $\overline{\alpha \beta \gamma}$ changes for World in the period 2006-2015

Rys. 1. Wielkość zmian $\overline{\alpha \beta \gamma}$ okresie 2006-2015 dla świata

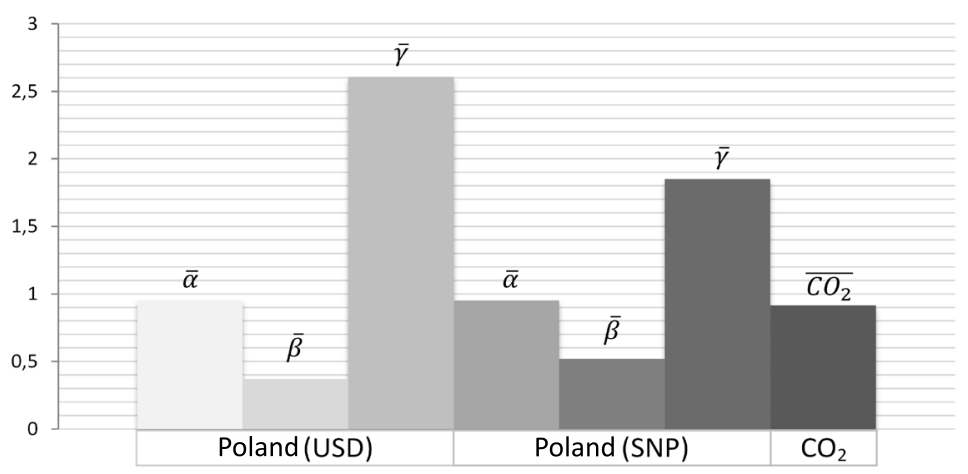

Fig. 2. $\overline{\alpha \beta \gamma}$ changes for Poland in the period 2006-2015

Rys. 2. Wielkość zmian $\overline{\alpha \beta \gamma}$ dla Polski w okresie 2006-2015 


\section{General characteristics of scenarios for fuel mix change until 2060}

As already noted, the changes occurring in the last decade in the fuel structure of primary energy consumption and used for the production of electricity significantly depended on the region and level of the economy. Table 2 shows that in the OECD and in all countries under consideration excluding China, a reduction in primary energy consumption has occurred. The reduction in electricity consumption per capita took place in countries with stabilized economies. In all cases, however, one observes a significant decrease in the emission output of the economy measured with the $E_{\mathrm{CO}_{2}} / \mathrm{GDP}$ indicator. It would be interesting to check whether the observed trends are characteristic for various published forecasts of the fuel situation in the power industry up to 2050 (60). Numerous development scenarios regarding the structure of primary energy consumption, electricity generation and the volume of carbon dioxide emissions are published (WEC 2016; IEA 2017b; EFDA 2017; EIA 2017; Shell 2017; BP 2017; IEA 2015). Let us, however, continue to focus mainly on the scenarios contained in (WEC 2016). The study considers three basic scenarios:

1. MODERN JAZZ (High economic growth, innovative economy - high impact of digitization on living conditions, dominance of free market mechanisms, high media influence on political decisions, dynamic changes of ruling elites, general access to energy);

2. UNFINISHED SYMPHONY (Domination of regulatory mechanisms - consumption taxes, pro-ecological incentives, moderate economic development, international organizational structures in the areas of safety, environment, and energy, strongly developed, innovative centralized energy);

3. HARD ROCK (Unstable economic growth - poverty and increase in social inequalities, ineffective international policy - political conflicts and occasional armed conflicts, centralized energy based on own, stable energy resources, unstable commodity prices, with periods of scarcity and peak prices).

The given specific assumptions for which the relevant forecasts have been drawn up relate to the world of 2060. In all scenarios, the average annual population growth of $0.7 \%$ was adopted (2014 - PLN 7,268 million, 2060 - 10,184). The other main data is contained in Table 3.

The first two scenarios assume a similar average growth rate of the world economy, while the third one is characterized by significantly lower GDP growth. None of the scenarios assumes development without increasing the primary energy consumption by 2060. In all cases, the increase in final energy consumption is higher than the primary energy consumption. Data on electricity production shows that the dynamics of change is similar for all scenarios. Scenario 1 (Modern Jazz) assumes the greatest production. The share of electricity in final consumption is similar for all scenarios, the average annual increase is 1.5 (scenarios 2 and 3) -1.7 (scenario 1) Significant differences, however, are observed in the anticipated carbon dioxide emission. The first two scenarios show a reduction (particularly significant for the second scenario), while the third one forecasts an emission increase. 
TABLE 3. Characteristic assumptions for the three considered scenarios considered (WEC 2016)

TABELA 3. Charakterystyczne założenia dla trzech rozważanych scenariuszy

\begin{tabular}{|l|c|c|c|c|}
\hline \multicolumn{1}{|c|}{ Scenarios } & $\begin{array}{c}\text { MODERN } \\
\text { JAZZ (1) }\end{array}$ & $\begin{array}{c}\text { UNFINISHED } \\
\text { SYMPHONY(2) }\end{array}$ & $\begin{array}{c}\text { HARD } \\
\text { ROCK (3) }\end{array}$ & Comments \\
\hline $\begin{array}{l}\text { Average annual GDP growth } \\
\text { 2014-2060 [\%] }\end{array}$ & 3.3 & 2.9 & 1.7 & $\begin{array}{c}\text { GDP 2014 - 70 trillion } \\
(70 \text { 1012) USD 2010 }\end{array}$ \\
\hline $\begin{array}{l}\text { Average annual increase in } \\
\text { primary energy consumption, } \\
2014-2060 \text { [\%] }\end{array}$ & 0.5 & 0.2 & 0.6 & $\begin{array}{c}\text { Primary energy 2014 - } \\
13,652 \text { Mtoe }\end{array}$ \\
\hline $\begin{array}{l}\text { Average annual increase } \\
\text { in electricity generation, } \\
\text { 2014-2060 [\%] }\end{array}$ & 1.6 & 1.4 & 1.4 & $\begin{array}{c}\text { Production 2014 - } \\
23,816 \text { TWh }\end{array}$ \\
\hline $\begin{array}{l}\text { Average annual increase in the } \\
\text { share of electricity in final ener- } \\
\text { gy consumption, 2014-2060 [\%] }\end{array}$ & 1.7 & 1.5 & 1.5 & $\begin{array}{c}\text { Electricity in final con- } \\
\text { sumption in 2014 - } \\
1701 \text { Mtoe }\end{array}$ \\
\hline $\begin{array}{l}\text { The average annual increase in } \\
\mathrm{CO}_{2} \text { emissions, 2014-2060 [\%] }\end{array}$ & -0.7 & -2.0 & 0.1 & $\begin{array}{c}\text { Emissions in 2014 - } \\
32.38 \text { Gt }\end{array}$ \\
\hline
\end{tabular}

(IEA 2017a; IEA 2015) features data for two scenarios. The first of them: the New Policies Scenario (NPS) was developed on the basis of the current policy and known plans for the future, while the second one is a scenario assuming that the temperature rise will stay under $2{ }^{\circ} \mathrm{C}(450$ Scenario). The forecasts concern 2040. The NPS assumes an average annual growth in the primary energy demand equal to $1 \%$ (from 13.8 billion toe in 2016 to 17.6 billion toe in 2040 ). These values exceed the forecast consumption in all WEC scenarios. They are the closest to the data contained in the Hard Rock scenario. The 450 scenario assumes an increase in consumption up to the level of 15.197 billion toe in 2040 ( $0.4 \%$ on average per year). The data corresponds to scenario 2 of the WEC. The final energy consumption in 2040 is forecast in both scenarios as follows: NPS - 12.538 billion toe (average annual growth between 2015-2040 1.1\%), scenario $450-10.706$ billion toe $(0.5 \%)$. Electricity production 2040: NPS - 39,444 TWh (average annual growth between 2015 2040 2\%), scenario 450 - 33,910 TWh (1.3\%). Emission of carbon dioxide 2040: NPS - 36,673 Gt (average annual increase between 2015-2040: 0.5\%), 450 - $18.777 \mathrm{Gt}(-2.1 \%)$.

The U.S. Energy Information Administration (EIA) is considering slightly different scenarios (EIA 2017). The starting point is the reference scenario, which was built based on the assumption of the continuous improvement of known technologies on the basis of the current state of knowledge and skills, taking the views of leading specialists in economic and demographic forecasts for 16 regions of the world into account. Ancillary scenarios were determined considering the variants of high economic growth (3.3\% annually on average in 2015-2040) and low growth $(2.7 \%)$ as well as options for high and low oil prices (the low price of USD 43 per barrel in 2040, reference scenario - USD 109 and the high price of USD 226). For the baseline scenario, primary energy consumption is estimated at 20.5 billion toe in 2040 (average annual increase between 2015 and 2040, about 1\%). For the variant of high economic growth, consumption increases to 19.6 billion toe (1.3\%). Electricity production (net) $2040-34000 \mathrm{TWh}$. Fairly stable emissions 
of carbon dioxide in the OECD countries, in the non-member countries these increase by an average of $1 \%$ per year. Total emissions 2040 - 37.5 Gt. Prognostic analyses in the (BP 2017) paper relate mainly to the period up to 2035. In addition, there is a rather general analysis carried out for a period until 2050. For the period between 2015 and 2035, GDP growth is assumed at 3.4\% per annum (the average annual GDP growth per capita $2.5 \%$ ). For this time period, population growth is forecast to increase by $0.9 \%$ per year, primary energy consumption is said to increase by $1.3 \%$ per annum (up to 17.2 billion toe in 2035 , approx. 18.0 billion toe -2040 ), increase in electricity production to 42,000 TWh (2.7\%). Emissions of carbon dioxide - 2035: $37.7 \mathrm{Gt}$ (increase by $0.6 \%$ per year). The (Shell 2017) paper focuses on fuel forecasts on a global scale and for individual continents up to 2100 . The demand for primary energy in 2050 is estimated at 20,300 Mtoe (in $2100-24000$ Mtoe, stabilization from 2075). Emissions of carbon dioxide $2050-27 \mathrm{Gt}$ (significant decrease after $2025-37.5 \mathrm{Gt}$ ).

\section{Analysis of the WEC scenarios}

The basic assumptions for which WEC scenarios have been developed are given in Table 3 . The characteristic differences between the assumptions are shown below, taking the fuel structure of electricity generation forecast for 2060 into account (Fig. 3-5). The largest volume of electricity production in 2060 occurs in scenario No. 1. This option corresponds to the greatest dynamics of electrification of the economy (see Table 3). Note that the smallest rate of withdrawal of carbon technologies is assumed in scenario No. 3 (Hard Rock). The share of coal in 2060 still remains relatively high, as it is $18 \%$, which, assuming $60 \%$ of the use of power capacity, gives the installed power around $1500 \mathrm{GW}$. Scenarios 1 and 2 include technologies with carbon dioxide capture installations. For scenario No. 2, there are no coal technologies without CCS in 2060. Interesting forecasts relate to gas energy. In addition to scenario No. 3, where the share of gas remains basically unchanged, in others between 2030 and 2060, it envisages the introduction of gas technologies from CCS. For scenario No. 2, this would appear to be the only option in 2060 (the share of gas technologies without CCS is only $2 \%$ ). The data on renewable energy technologies is also worth mentioning. Basically, there is no dominant technology. Wind and solar technologies have similar shares in production. In scenario No. 2, the share of non-fossil fuels is $81 \%$. The share of nuclear energy is stable. As shown in Table 3, the emissions of carbon dioxide decrease the fastest for scenario No. 2 ( $-2 \%$ on average annually), whereas in scenario No. 3 these emissions are growing, as in many other forecasts (e.g. the NPS IEA scenario, the BP or EIA reference scenario). It is worth emphasizing that according to scenario No. 2 no carbon dioxide emissions in the electricity generation sector are expected in 2060. The impact of individual indicators on the emission effect can be traced in the period under consideration using the relationship (1.1) or, in the case of the emissions per capita from (1.2) and (1.3). The relevant values of these ratios are presented in Table 4 (calculations based on IEA 2008; WEC 2016). For 2014, 


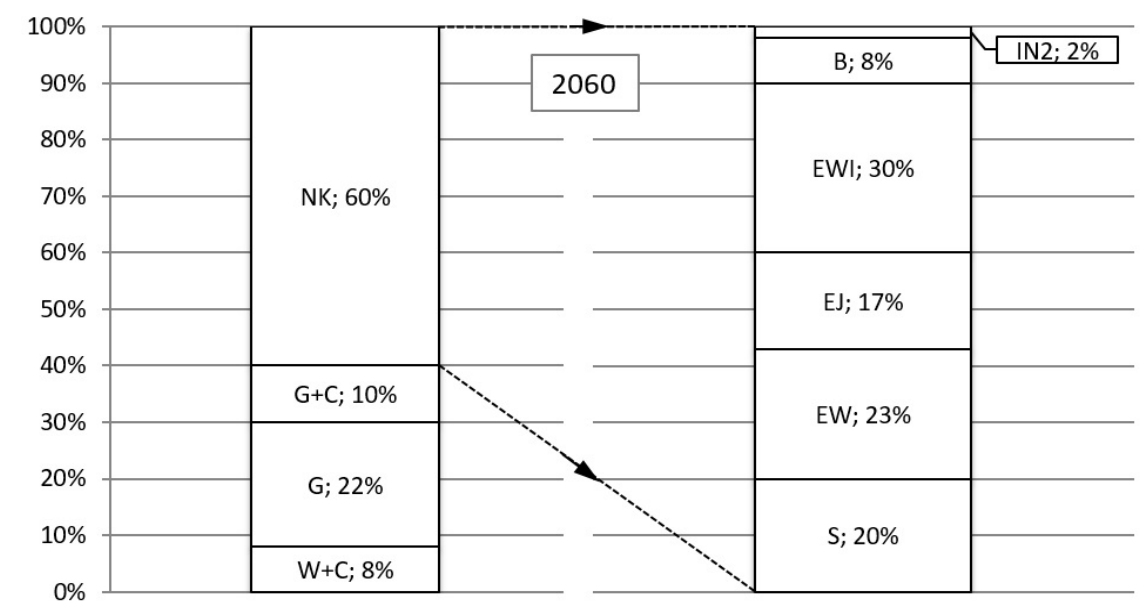

Fig. 3. Fuel structure of electricity generation for the MODERN JAZZ scenario in 2060. Total production 48,491 TWh. $\mathrm{W}+\mathrm{C}-\operatorname{coal}(2 \%)$ and coal with CCS $(6 \%), \mathrm{G}-$ gas, $\mathrm{G}+\mathrm{C}-$ gas with CCS, NK - non-fossil fuels with nuclear energy, $\mathrm{S}$ - solar energy, EW1 - wind energy, EW - hydropower, EJ - nuclear power, IN2 - other (geothermal energy, biomass from CCS), B - biomass

Rys. 3. Struktura paliwowa wytwarzania elektryczności dla scenariusza MODERN JAZZ w 2060 r. Łączna produkcja $48491 \mathrm{TWh}$

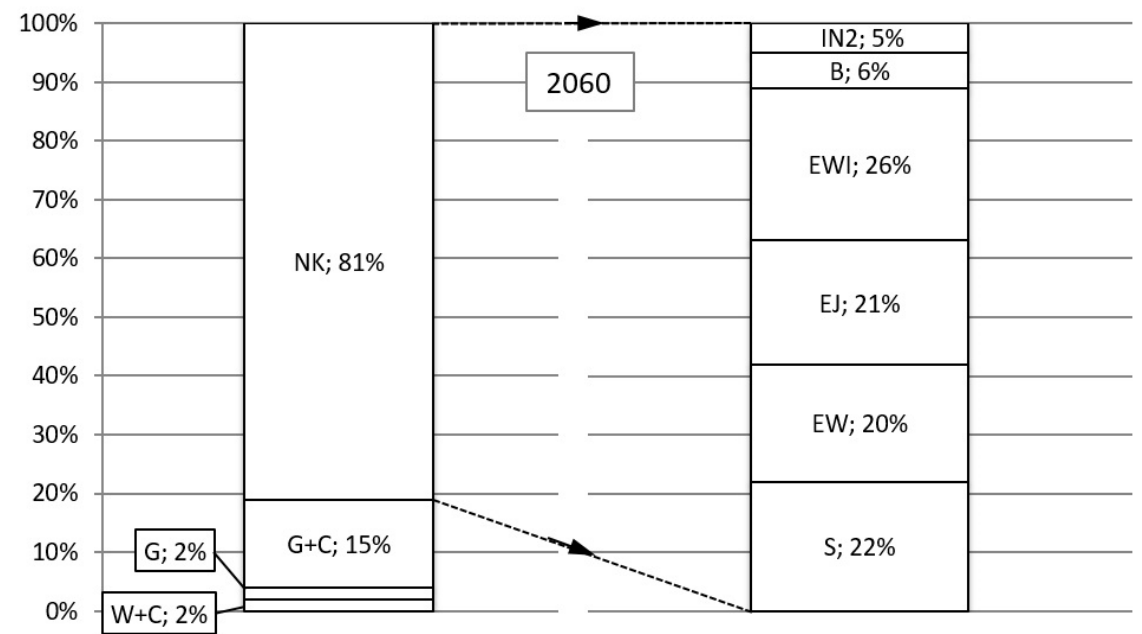

Fig. 4. Fuel structure of electricity generation for the UNFINISHED SYMPHONY scenario in 2060. Total production 44,474 TWh. Notations as in Fig. 3

Rys. 4. Struktura paliwowa wytwarzania elektryczności dla scenariusza UNFINISHED SYMPHONY w 2060 r. Łączna produkcja 44474 TWh. Oznaczenia jak na rys. 3 


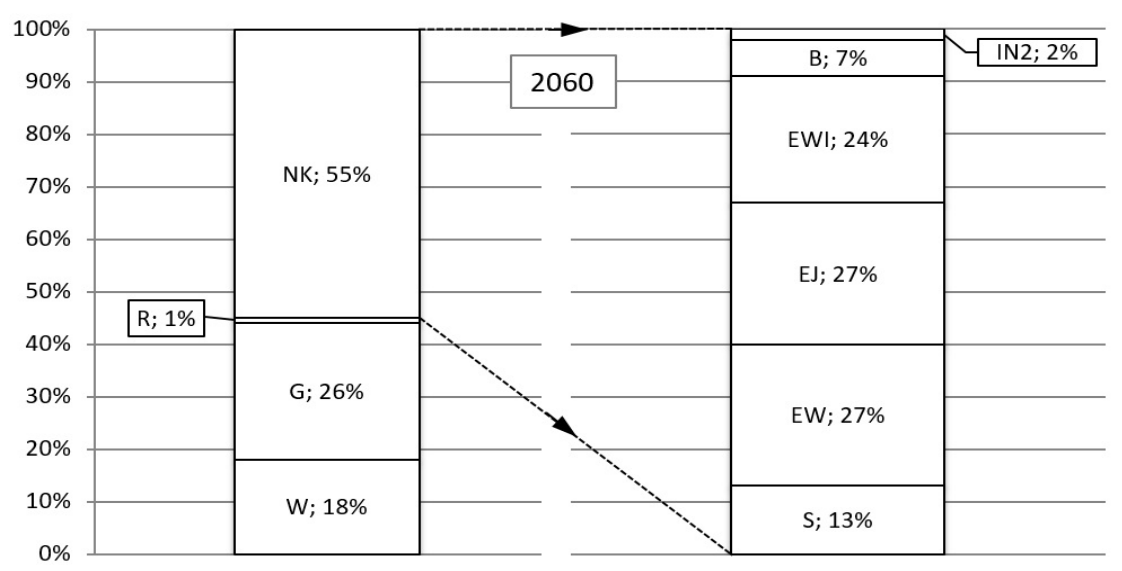

Fig. 5. Fuel structure of electricity generation for the HARD ROCK scenario in 2060. Total production 44,914 TWh. $\mathrm{R}-$ oil. Other notations as in Fig. 3 and 4

Rys. 5. Struktura paliwowa wytwarzania elektryczności dla scenariusza HARD ROCK w 2060 r. Łączna produkcja 44914 TWh. R - ropa. Pozostałe oznaczenia jak na rys. 3 i 4

all scenarios include $\alpha=0.057, \beta=8.16, \gamma=9.63, \bar{E}_{\mathrm{CO}_{2}}=4.49$. For all scenarios, the change of the emissions per capita is more intense than the change in absolute emission. The dynamics of emission changes in the analyzed cases is mainly determined by the energy intensity of national income $(\beta)$ and the change in the fuel mix $(\alpha)$. These two indicators decided on the smallest value of $\overline{C O}_{2}$ the scenario No. 2. In the analysis of changes in emissions in the period 2006-2015, a small impact of the fuel mix for emissions at that time was observed. Data for scenarios 1 and 2 show how significant changes in fuel structure must take place in order to achieve the desired effect. A similar effort is required in the field of energy efficiency. The data shown is valid for the entire globe. For individual regions and countries, the data will vary greatly as a consequence of a different growth dynamics of national income, a different population change, and energy in-

TABLE 4 . Value of the $\alpha, \beta, \gamma$ indicators for scenarios $1-3$

TABELA 4. Wartości wskaźników $\alpha, \beta, \gamma$ dla scenariuszy 1-3

\begin{tabular}{|l|c|c|c|}
\hline \multicolumn{1}{|c|}{ Indicators } & Scenario 1 & Scenario 2 & Scenario 3 \\
\hline $\begin{array}{l}\bar{\alpha} \text { (Average annual change in the period } \\
2014-2060[\%])\end{array}$ & $0.57(-1.2)$ & $0.35(-2.2)$ & $0.78(-0.54)$ \\
\hline $\begin{array}{l}\bar{\beta} \text { (Average annual change in the period } \\
2014-2060[\%])\end{array}$ & $0.28(-2.7)$ & $0.302(-2.6)$ & $0.62(-1.0)$ \\
\hline $\begin{array}{l}\bar{\gamma} \text { (Average annual change in the period } \\
2014-2060[\%])\end{array}$ & $3.18(+2.5)$ & $2.61(+2.1)$ & $1.53(+0.92)$ \\
\hline $\begin{array}{l}\overline{C O}_{2} \text { Average annual change in the period } \\
2014-2060[\%])\end{array}$ & $0.51(-1.5)$ & $0.28(-2.8)$ & $0.74(-0.63)$ \\
\hline
\end{tabular}


tensity of national income. For instance, in the case of China, the following average annual GDP growth is expected: $4.3 \%$ (Scenario No. 1), $4.0 \%$ (2), and $2.8 \%$ (3). Changes in energy intensity of GDP: $\bar{\beta}=-3.8 \%$ (1), $-3.8 \%$ (2), and $-2.3 \%$ (3). These values deviate significantly from the values for Europe 31 (EU + Switzerland, Norway, and Iceland), for which the relevant data is: GDP -1.85 (1), $1.7 \%$ (2), $0.6 \%(3) ; \bar{\beta}=-2.2 \%$ (1), $-2.2 \%$ (2), and $-0.7 \%$ (3).

\section{Scenario analysis in Poland}

Various scenario analyses are carried out in Poland. None of them, however, have been officially supported. The study (MG 2015) presents basic data resulting from studies (KAPE 2013; ARE 2013; NTUA 2013; IGSMiE 2013; SEP 2014). many variants differing in the assumptions with regard to the dynamics of growth in demand for electricity, prices of carbon dioxide emission allowances, policy on nuclear energy as well as access to new coal deposits were considered therein. The multitude of scenarios makes it difficult to compare them. In general, one may conclude that, according to various forecasts, the expected electricity generation in 2050 will be in the range of 200-250 (275) TWh, which gives an average annual increase in demand in the period 2015-2050 at the level of $0.8-1.0 \%$. This value is significantly lower than in IEA scenarios $1-3$. The forecast for the same scenarios is also the demand for primary energy. Data specific to scenarios analyzed in the study (MG 2015) show a slight increase in primary energy generation in the case of some forecasts $(0.25 \%$, NTUA 2013), while national forecasts are characterized by a slight decrease $(0.3 \%)$ (e.g. KAPE 2013). The fuel structure of electricity generation is similar for many scenarios, the most similar to IEA scenario No. 3. For instance, the forecast (KAPE 2013 ) for 2050 points to the following structure: coal $38 \%$, gas $9.2 \%$, RES $32.8 \%$, EJ $19.4 \%$, other $0.6 \%$. Among other forecasts, attention may be paid to the study (DAS 2013). It may seem interesting, for instance, because of a rather detailed description of the model and analysis of the impact of carbon dioxide emission costs. In addition, it should be emphasized that Polish forecasts predict generally high dynamics of the decrease in the energy intensity of GDP, similar to IEA scenarios 1 and 2 (annual average $-2.7 \%$ ).

\section{Final comments}

Numerous organizations put forward scenarios with regard to the future fuel and technological energy structure. These have been developed in order to execute various assumptions related to the pace of economic development, population growth, and development of the political 
situation as well as the situation on the fuel market. For this reason, it would appear difficult to assess their reliability. Nevertheless, the analysis thereof may facilitate guiding the necessary technological development for achieving economic and ecological goals. The scenarios may also pinpoint developmental constraints resulting from the adopted assumptions and emerging political uncertainties. The construction of development scenarios for Poland must include analyses for the entire globe and individual regions thereof, as well as the limits of own raw material base. The forecasts proposed so far have not been consistent enough. This requires a deeper synthesis and assessment of scenarios proposed by various institutions and taking a closer look at the methodological approaches applied in the development thereof. The analysis of the scenarios considered in the study would imply that Polish analyses may be based on assumptions adopted for the HARD ROCK scenario. The starting point in Poland suggests a relatively high share of coal in the production of electricity in the next two decades. However, fundamental decisions which will shape the evolution of the Polish fuel mix relate to nuclear energy and the role of gas technologies in production of the electricity. Having no clarity on these two fundamental issues, it appears somewhat challenging to forecast the technological development of energy in Poland by 2040 (50). Without the high dynamics of gas introduction into the power industry, it will be difficult to increase the share of renewable energy and significantly reduce the emission intensity of the power industry and the entire economy.

\section{References}

IEA 2017a - Key World Energy Statistics, International Energy Agency (IEA).

IEA 2008 - Key World Energy Statistics, IEA, 2008.

KPE PAN 2010 - Fuel, technological, and ecological challenges for the Polish energy. Ed. T. Chmielniak,

M. Pawlik, J. Malko, J. Lewandowski. Study of the Committee for Energy Problems of the State Academy of Sciences, Publishing House of the Silesian University of Technology Gliwice (in Polish).

WEC 2016 - World Energy Scenarios. The grand transition. World Energy Counsil (WEC) London.

IEA 2017b - Key World Energy Statistics, International Energy Agency - limited data up to 2040.

EFDA 2017 - Final Report - Global Energy Scenarios European Fusion Development Agreement WP12-

SER ETM - review and discussion on various scenarios.

EIA 2017 - International Energy Outlook. U.S. Energy Information Administration.

Shell 2017. Shell World Energy Modell. A view to 2100.

BP 2017 - Energy Outlook 2017 Edition.

IEA 2015 - World Energy Outlook. International Energy Agency.

MG 2015 - Conclusions from prognostic analyses purposes of the Polish Energy Policy up to 2050. Annex

2. Ministry of Economy (Wnioski z analiz prognostycznych na potrzeby Polityki energetycznej Polski

do 2050 roku. Załacznik 2. Ministerstwo Gospodarki). Warsaw (in Polish).

KAPE 2013. Forecast of fuel and energy demand by 2050 (Prognoza zapotrzebowania na paliwa i energie do 2050 roku). Krajowa Agencja Poszanowania Energii SA (in Polish).

ARE 2013. Update of the forecast for fuel and energy demand by 2030 (Uaktualnienie prognozy zapotrzebowania na paliwa i energię do roku 2030). Agencja Rynku Energii SA, Warsaw (in Polish).

NTUA 2013 - Poland: Reference Scenario 2013, National Technical University of Athens for European Commission. 
IGSMiE 2013 - The forecast of the Polish economy's demand for hard and brown coal as a raw material for the power industry in the perspective of 2050 (Prognoza zapotrzebowania gospodarki polskiej na wegiel kamienny i brunatny jako surowca dla energetyki w perspektywie 2050 roku). Institute of Economy of Mineral Resources and Energy of the Polish Academy of Sciences, Kraków (in Polish).

SEP 2014 - Expert opinion on the forecast of seven variants of developments in the power sector up to 2050, including the base scenario - business as usual (Ekspertyza dotyczaca prognozy siedmiu wariantów rozwoju sytuacji $w$ sektorze elektroenergetycznym $w$ horyzoncie do 2050 roku, $w$ tym scenariusz bazowy - business as usual). Association of Polish Electrical Engineers (in Polish).

DAS 2013 - The model of the optimal energy mix for Poland by 2060. Version 2.0 (Model optymalnego miksu energetycznego dla Polski do roku 2060. Wersja 2.0). Department of Strategic Analysis. The Chancellery of the Prime Minister. Warsaw (in Polish).

\section{Struktura paliwowa potrzeb energetycznych globu według różnych scenariuszy rozwoju}

\section{Streszczenie}

Celem artykułu jest analiza tendencji zmian w strukturze paliwowej wytwarzania elektryczności oraz stąd wynikających zmian emisji ditlenku wegla. Do analizy wybrano prognozy opracowane prze różne instytucje i organizacje. Najpierw na podstawie danych statystycznych zawartych w (IEA 2017a; IEA 2008) przeanalizowano z wykorzystaniem wskaźników Kaya wpływ zmian energochłonności dochodu narodowego i miksu energetycznego na zmianę emisji ditlenku węgla per capita w okresie 2006-2015 dla krajów OECD i Polski. Stwierdzono niewielki wpływ zmian miksu paliwowego w tym okresie czasu na emisję. Podstawowy wpływ miały zmiany energochłonności dochodu narodowego oraz zmiany dochodu narodowego per capita. Następnie omówiono wybrane scenariusze paliwowe do 2050 (60) r. - WEC, IEA, EIA, BP, Shell; szczególną uwagę skupiając na scenariuszach WEC. Zostały one opracowane dla różnych założeń dotyczących tempa rozwoju gospodarczego, wzrostu populacji oraz rozwoju sytuacji politycznej i sytuacji na rynku paliw. $Z$ tego powodu ich wiarygodność jest trudna do oceny. Przedyskutowano głównie dane dotyczące struktury paliwowej wytwarzania elektryczności oraz energochłonności dochodu narodowego i zmian emisji ditlenku węgla. W ostatniej części artykułu przeprowadzono ogólną analizę prognoz opracowanych dla Polski. Są one dość zróżnicowane, część z nich została opracowana w ramach przygotowania Polityki Energetycznej Polski do 2050 r., część obejmuje okres do 2035 r. Zauważono, że niektóre prognozy dają podobne wyniki, jakie są charakterystyczne dla scenariusza Hard Rock WEC.

SŁOWA KLUCZOWE: scenariusze energetyczne do 2060, struktura paliwowa wytwarzania elektryczności, zmiany w emisji ditlenku węgla, scenariusze energetyczne dla Polski 
